\title{
Analisis Upaya Menurunkan Cacat Produk Crank Case LH pada Proses Die Casting dengan Metode PDCA dan FMEA di PT. Suzuki Indo Mobil/Motor
}

\author{
Dimas Raya ${ }^{1}$, Agustinus Yunan ${ }^{* 2}$, Rifda Ilahy Rosihan ${ }^{3}$ \\ Program Studi Teknik Industri, Fakultas Teknik, Universitas Bhayangkara Jakarta Raya \\ e-mail: ${ }^{1}$ dimasraya240395@gmail.com, ${ }^{* 2}$ agustinus.yunan@dsn.ubharajaya.ac.id, \\ rifda.ilahy@dsn.ubharajaya.ac.id
}

\begin{abstract}
PT. Suzuki Indo Mobil / Motorcycle is the largest motorcycle manufacturing industry in Indonesia today. Die Casting is one of the departments that is important in the manufacture of motorcycle parts. In the Die Cating section, there are a number of types of defects that exceed the company tolerance standards. During the February to July period, 228 pcs of defect products were found. For this reason, it is necessary to determine the most dominant factor in the occurrence of defects and determine the proposed improvement of the root problem. PDCA is a useful tool for continuous improvement and FMEA or Failure Mode Analysis is a tool that is often used in quality improvement methods. FMEA serves to determine the consequences of failure associated with failure in the Crank Case LH. There are three types of defects found, namely Chipped, Cracked, Wrinkled. With pareto diagram, it is known that there are three types of defect Crank Case LH which are the most dominant, namely: $9.9 \%$ chipped, Crack 6.75\%, Wrinkles 4.72\%. aluminum \& mold is too low, engine filling time is too long, Crank Case LH Cracks the surface of the rough molding machine, engine pressure is too large, Crank Case LH Machine wrinkles Less pressure. Improve made is to make a standard number of Crank Case LH setting parameters of the engine and required $S O P$.
\end{abstract}

Keywords: Defect, Quality Control, PDCA, FMEA

\begin{abstract}
ABSTRAK
PT. Suzuki Indo Mobil / Motor adalah industri manufaktur sepeda motor terbesar di Indonesia saat ini. Die Casting adalah salah satu departemen yang penting dalam pembuatan suku cadang sepeda motor. Di bagian Die Cating, ada sejumlah jenis cacat yang melebihi standar toleransi perusahaan. Selama periode Februari hingga Juli, 228 pcs produk cacat ditemukan. Untuk alasan ini, perlu untuk menentukan faktor yang paling dominan dalam terjadinya cacat dan menentukan perbaikan yang diusulkan untuk masalah akar. PDCA adalah alat yang berguna untuk peningkatan berkelanjutan dan FMEA atau Failure Mode Analysis adalah alat yang sering digunakan dalam metode peningkatan kualitas. FMEA berfungsi untuk menentukan konsekuensi dari kegagalan yang terkait dengan kegagalan dalam Crank Case LH. Ada tiga jenis cacat yang ditemukan, yaitu Chipped, Cracked, Wrinkled. Dengan diagram pareto, diketahui bahwa ada tiga jenis cacat Crank Case LH yang paling dominan, yaitu: 9,9\% terkelupas, Retak 6,75\%, Keriput 4,72\%. aluminium \& cetakan terlalu rendah, waktu pengisian mesin terlalu lama, Crank Case LH Memecah permukaan mesin cetak kasar, tekanan mesin terlalu besar, Crank Case LH Machine keriput Lebih sedikit tekanan. Peningkatan yang dilakukan adalah dengan membuat sejumlah standar parameter pengaturan Crank Case LH dari engine dan SOP yang diperlukan.
\end{abstract}

Kata Kunci: Defect, Quality Control, PDCA, FMEA 


\section{PENDAHULUAN}

Industri manufaktur sepeda motor merupakan perusahaan terbesar di Indonesia saat ini. Die Casting merupakan salah satu dapartemen yang berperan penting dalem pembuatan part sepeda motor. Industri manufaktur sepeda motor di Indonesia terus berkembang sejalan dengan kebutuhan masyarakat dan jumlah penduduk yang cukup besar, sehingga profit yang diperoleh sangat menjanjikan, dan terjadi persaingan yang ketat di dalam industri manufaktur sepeda motor. Industri tersebut, selain memenuhi kebutuhan pasar lokal, sekarang ini telah mencapai pasar internasional.

PDCA merupakan siklus umpan balik terus menerus di mana sistem, proses atau individu melaksanakan suatu proses yang terencana, dievaluasi, kemudian mendapatkan umpan balik, melakukan perbaikan dan kembali pada perencanaan yang secara siklus berlangsung terus menerus melakukan perbaikan. Selain PDCA metode pengendalian kualitas itu ada beberapa macam yaitu penulis memilih FMEA sebagai perbandingan terhadap metode PDCA.

FMEA merupakan sebuah alat yang digunakan untuk mengidentifikasi dan menilai resiko yang berhubungan dengan potensial kegagalan.

Contoh produk seperti Crank Case LH. Masalah yang terjadi pada Die Casting ini yaitu sering terjadi cacat pada produk Crank Case LH sedangkan penyebab dari kecacatan tersebut belum diketahui. Karena tuntutan kualitas yang sangat menentukan eksistensi produk maka penyimpangan terhadap produk cacat yang dihasilkan harus dihilangkan semaksimal mungkin. Maka dari itu penulis berusaha mencari pemecahan masalah tersebut dengan menggunakan metode PDCA dan FMEA. Data cacat pada produk tersebut antara lain dapat dilihat di bawah ini

Tabel 1 Jumlah Cacat Crank Case LH / Jenis Cacat Crank Case LH dan angka Defect kecacatan Crank Case LH bulan Febuari-Juli 2018

\begin{tabular}{|c|c|c|c|c|c|c|c|c|c|c|c|c|c|c|}
\hline \multirow{3}{*}{ Jenis Defect } & \multicolumn{12}{|c|}{ Buna } & \multirow{3}{*}{ Iotal } & \multirow{3}{*}{$16(10)$} \\
\hline & \multicolumn{2}{|c|}{$18 \mathrm{Fel}$} & \multicolumn{2}{|c|}{ 18Hal" } & \multicolumn{2}{|c|}{$18.1 p$} & \multicolumn{2}{|c|}{ 18Jei } & \multicolumn{2}{|c|}{ 18Juin } & \multicolumn{2}{|c|}{$18 \mathrm{WW}$} & & \\
\hline & Prs & Defeet & Pos & Defect & Pis & Defeet & PQS & Defert & Pis & Defert & Pos & Defect & & \\
\hline $\begin{array}{c}\text { Cratcaxif } \\
\text { Gomal }\end{array}$ & 18 & 1366 & 16 & 1088 & It & 8.18 & 18 & $6.90^{\circ}$ & $1 i$ & $8 \%$ & 16 & 1260 & $10^{\circ}$ & 99 \\
\hline $\begin{array}{c}\text { Cratcaxif } \\
\text { Retid }\end{array}$ & 10 & 4.87 & It & $9: 2$ & 10 & iN & 15 & $\$ 81$ & If & 813 & 8 & 634 & 7 & $67 \%$ \\
\hline $\begin{array}{c}\text { Cratcaxif } \\
\text { ringt }\end{array}$ & i & 3.4 & 11. & 68 & i & 4.10 & 11 & 4.6 & 10 & $\$ 81$ & ; & 3,96 & in & $4 \%$ \\
\hline TodilDefety & & 1521,49 & H & 211 & 31 & 18,11 & H & 17 & 39 & $2.66^{\circ}$ & 19 & 13 & 228 & \\
\hline Totalproditi & & 115 & & 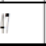 & & 1 & 2 & 8 & 1 & ? & & 1.6 & $1.0 \%$ & \\
\hline TyytPencisum & & & & & & & IVI & 14 & & & & & & \\
\hline
\end{tabular}

Sumber: Data Perusahaan (2018)

Berdasarkan pada table di atas dapat dilihat bahwa telah terjadi produk cacat pada Crank Case LH, selama 6 bulan dari Febuari 2018 sampai dengan bulan Juli 2018. Meningkatnya produk cacat terlihat pada jenis cacat Crank Case LH Gompal dengan total 107 unit dengan total presentase 10,18 \%. Crank Case LH retak dengan total 71 unit dengan total presentasi $6,75 \%$. Crank Case LH Keriput dengan total 50 unit dengan total presentasi 4,72,hal ini melebihi target yang telah ditetapkan perusahaan yakni sebesar $2 \%$. Untuk mengurangi tingkat hasil kecacatan suatu produk maka penulis menggunakan metode PDCA (Plan Do Check Action) dan FMEA (Failure Mode Effect Analysis)

\subsection{Rumusan Masalah}

Berdasarkan latar belakang dan identifikasi masalah yang telah diuraikan, maka rumusan masalah dalam penelitian ini adalah :

1. Faktor - faktor apa saja yang menyebabkan terjadinya produk

2

Analisis Upaya Menurunkan Cacat Produk Crank Case LH pada Proses Die Casting dengan Metode PDCA dan 
cacat / NG (not good) pada produk Crank Case LH?

2. Bagaimana solusi perbaikan ketidak sesuaian produk cacat yang dapat di usulkan untuk menurunkan produk cacat / NG (not good) tersebut pada Crank Case LH?

\subsection{Tujuan Penelitian}

Adapun tujuan yang hendak dicapai dari sebuah penelitian ini adalah sebagai berikut :

1. Menentukan akar masalah dominan penyebab produk cacat / NG (not good) pada produk Crank Case LH

2. Menentukan usulan pengendalian kualitas produk Crank Case $\mathrm{LH}$ dengan menggunakan metode PDCA dan FMEA

\subsection{Definisi Kualitas}

Berbagai pandangan bermunculan mengenai apa definisi tentang "kualitas" pemikiran dasarnya saat ini konsumen akan mencari dan membeli barang dan jasa yang berkualitas entah itu konsumen perorangan, organisasi swasta atau organisasi pemerintah. Ketika ingin membeli barang dan jasa tersebut, konsumen datang dengan membawa tiga aspek yakni kebutuhan, ekspentasi dan harapan. Sebelum kita membahas definisi dari "kualitas" terlebih dahulu harus dikupas makna dari ketiga aspek tersebut.

\subsection{Tujuan Pengendalian Kualitas}

Dukungan manajemen, karyawan, dan pemerintah untuk perbaikan kualitas adalah penting untuk kompetisi yang efektif di pasar global. Untuk menjaga konsistensi kualitas produk dan jasa yang dihasilkan dan sesuai dengan tuntutan kebutuhan pasar, perlu dilakukan pengendalian kualitas (quality control) atas aktivitas proses yang dijalani.

\subsection{Pengertian Produk Cacat}

Produk cacat merupakan produk gagal yang secara teknis atau ekonomis masih dapat diperbaiki menjadi produk yang sesuai dengan standar mutu yang ditetapkan tetapi membutuhkan biaya tambahan. Dalam proses produksi, produk cacat ini dapat diakibatkan oleh dua hal, yaitu: disebabkan oleh spesifikasi pemesan (abnormal) dan disebabkan oleh faktor internal (normal).

\subsection{PDCA (Plan Do Check Action)}

Menurut (Zullian yamit, 2013) pola PDCA dikenal sebagai "siklus shewart" karena pertama kali dikemukakan oleh walter shewat beberapa puluh tahun lalu. Namum dalam perkembangannya metodologi analisa PDCA lebih sering disebut "siklus deming" . hal ini karena deming adalah orang yang mempopulerkan dan memperluas penerapannya. Dengan nama apa pun itu disebut PDCA adalah alat bermanfaat untuk melakuan perbaikan secara terus menerus (continuous improvement) tanpa berhenti. (Edward deming), memopulerkan konsep PDCA (Plan, Do, Check, Act) sebagai metode ilmiah dalam pengelolaan (manajemen) suatu proses bisnis. PDCA meliputi empat kegiatan, yaitu percencanaan (plan), eksekusi $(d o)$, pemeriksaan (check), dan tindakan koreksi atau perbaikan (act).

1. menentukan tujuan dan sasaran (Plan)

2. melaksanakan perkerjaan (Do)

3. Melaksanakan Evaluasi (Check)

4. Melaksanakan Action

\subsection{FMEA (Failure Mode Effect} Analysis)

Suatu prosedur untuk terstruktur untuk mengidentifikasi dan mencegah sebanyak mungkin mode kegagalan. Suatu 
mode kegagalan adalah apa aja yang termasuk dalam kecacatan, kondisi diluar spesifikasi atau perubahan dalam produk yang menyebabkan terganggunya fugsi dari produk. tahap-tahap menerapkan FMEA adalah sebagai berikut :

1. Deskripsi dan tujuan

2. Mengidentifikasi modus kegagalan pontesial

3. Menentukan rating keparahan (severity)

4. Menentukan rating kejadian (occurrence)

5. Indetifikasi tingkat deteksi (detection)

6. Menghitung Risk Priority Number (RPN)

1.8 Tujuh Alat Kualitas (Seven Tools) Berikut ini adalah tujuh tools pengukuran kualitas:

1. Flow Chart

2. Diagram Sebab Akibat (Fishbone)

3. Check Sheet

4. Pareto Chart

5. Histogram

6. Scatter Diagram

7. Control Chart

\section{METODE PENELITIAN}

Penelitian ini dilakukan adalah analisis penegndalian kualiatas pada proses produksi Crank Case $L H$ dan produk lainnya dengan metode PDCA dan FMEA di PT Suzuki Indo Motor.

Dalam penyelesaian skripsi ini penulis menggunakan metode kualitatif dan kuantitatif sehingga mendapatkan data-data berupa angka mengenai jumlah produk cacat dalam suatu proses produksi. Adapun data-data tersebut di peroleh dari department QC dan depaterment lainya yang berkaitan dengan penelitian ini Metode pengamatan merupakan suatu serangkaian kegiatan yang bertujuan untuk mengetahui situasi atau kondis lingkungan

Metode Kualitatif merupakan analisis yang memberikan gambaran umun perusahaan untuk mengevaluasi dan menilai program-program pengendalian kualitas yang ditinjau dari penerapanpenerapan unsur dan pendukung program dari penegendalian kualitas. Metode kuatitatif yaitu analisis yang berdasarkan dari Data yang dapat dianalisis dengan teknik analisis kuantitatif adapun datadata tersebut meliputi data produk cacat periode Febuari hingga Juli 2018

Setelah data terkumpul dan diidentifikasi maka selanjutnya penulis mengelolah data tersebut sesuia dengan tujuan dan pemecahan masalah. Adapun langkah-langkah dalam pengolahan data adalah sebagai berikut:

1. Identifikasi masalah bertujuan untuk mengetahui seberapa besar produk yang cacat selama beberapa bulan terakhir. Penulis mengindentifikasi masalah ini ke dalam bentuk check sheet, kemudian di gambarkan dengan memakai diagram paretto

2. Menentukan faktor utama terjadinya produk yang cacat dengan cara menganalisa sebab akibat. Berisi tentang analisa timbulnya suatu akibat, dan mencari faktor-faktor penyebab terjadinya produk yang cacat, penulis menggambarkan diagram dengan menggunakan diagram fishbone

3. Melakukan uji coba perbaikan lingkungan kerja dan langkahlangkah proses pembuatan produk Crank Case LH dan produk lainnya yang akan diuji coba. Tujuannya untuk mengetahui apakah masih ada masalah atau tidak didalam proses produksi

4

Analisis Upaya Menurunkan Cacat Produk Crank Case LH pada Proses Die Casting dengan Metode PDCA dan 
4. Memeriksa hasil perbaikan, berisi tentang penulis memeriksa atau mengevaluasi hasil dari perbaikan

5. Standarisasi hasil, setelah memeriksa hasil dari tes uji coba penulis melakukan standarisasi agar tidak terjadi masalah atau produk yang cacat pada saat proses produksi

6. Setelah melakukan standarisasi, penulis melakukan implementasi secara berkesinambungan dan membeikan ususlan kepada perusahaan

\subsection{Flow Chart Penelitian}

Flow Chart pada penelitian ini dapat dilihat pada Gambar 1.

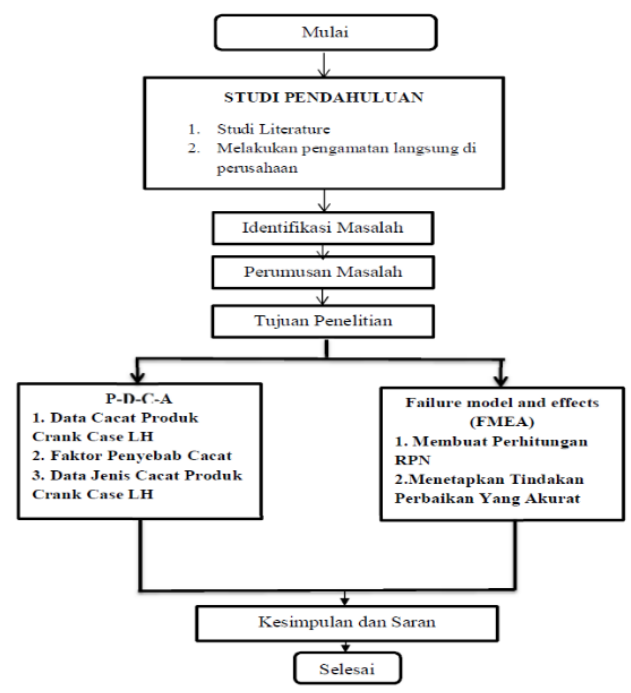

Sumber: Pengolahan Data (2019)

Gambar 1. Flow chart Penelitian

\section{HASIL DAN PEMBAHASAN}

\subsection{Pengumpulan Data}

Tabel 2 merupakan data produk cacat bulan Februari sampai dengan Juli 2018
Tabel 2 Data Produk Cacat Febuari hingga Juli 2018

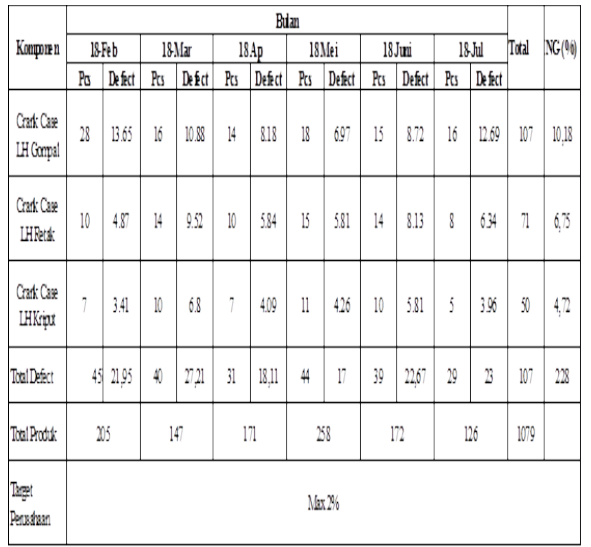

Sumber: Data Perusahaan (2018)

\subsection{Menentukan Tujuan dan Sasaran (Plan)}

Dalam menentukan tujuan dan sasaran. Agar mendapatkan data penyimpangan atau kondisi yang tidak baik, yang berhubungan dengan akar permasalahan

Tabel 3 Check Sheet Data Problem Kualitas Febuari - Juli 2018

\begin{tabular}{|c|c|c|c|c|c|c|}
\hline \multirow{7}{*}{ No } & \multirow{7}{*}{$\mathrm{Tgl} / \mathrm{B} \ln / \mathrm{Thn}$} & \multirow{7}{*}{$\begin{array}{c}\text { Jumlah } \\
\text { Proble } \\
\text { m }\end{array}$} & \multirow{7}{*}{$\begin{array}{c}\text { Total } \\
\text { Proses } \\
\text { Perbaik } \\
\text { a }\end{array}$} & \multicolumn{3}{|c|}{ Jenis Problem } \\
\hline & & & & Crank & Cran & Cran \\
\hline & & & & Case & $\mathrm{k}$ & $\mathrm{k}$ \\
\hline & & & & LH & Case & Case \\
\hline & & & & Gomp & LH & $\mathrm{LH}$ \\
\hline & & & & al & Reta & Keri \\
\hline & & & & & $\mathrm{k}$ & put \\
\hline 1 & $18-31 / 1 / 2018$ & 16 & 55 & 11 & 4 & 3 \\
\hline 2 & $1-9 / 2 / 2018$ & 15 & 53 & 9 & 3 & 2 \\
\hline \multirow[t]{2}{*}{3} & $10-18 / 2 / 2018$ & 14 & 52 & 8 & 3 & 2 \\
\hline & Total & 45 & 160 & 28 & 10 & 7 \\
\hline 4 & $18-28 / 2 / 2018$ & 14 & 36 & 6 & 5 & 4 \\
\hline 5 & $1-9 / 3 / 2018$ & 13 & 36 & 5 & 5 & 3 \\
\hline \multirow[t]{2}{*}{6} & $10-18 / 3 / 2018$ & 13 & 35 & 5 & 4 & 3 \\
\hline & Total & 40 & 107 & 16 & 14 & 10 \\
\hline 7 & $18-31 / 3 / 2018$ & 11 & 47 & 5 & 4 & 3 \\
\hline 8 & $1-9 / 4 / 2018$ & 10 & 47 & 5 & 3 & 2 \\
\hline \multirow[t]{2}{*}{9} & $10-18 / 4 / 2018$ & 10 & 46 & 4 & 3 & 2 \\
\hline & Total & 31 & 140 & 14 & 10 & 7 \\
\hline 10 & $18-30 / 4 / 2018$ & 15 & 72 & 6 & 5 & 4 \\
\hline 11 & $1-9 / 5 / 2018$ & 15 & 71 & 6 & 5 & 4 \\
\hline \multirow[t]{2}{*}{12} & $10-18 / 5 / 2018$ & 14 & 71 & 6 & 5 & 3 \\
\hline & Total & 44 & 214 & 18 & 15 & 11 \\
\hline 13 & $18-31 / 5 / 2018$ & 13 & 45 & 5 & 5 & 4 \\
\hline 14 & $1-9 / 6 / 2018$ & 13 & 44 & 5 & 5 & 4 \\
\hline \multirow[t]{2}{*}{15} & $10-18 / 6 / 2018$ & 13 & 44 & 5 & 4 & 3 \\
\hline & Total & 39 & 133 & 15 & 14 & 10 \\
\hline 16 & $18-30 / 6 / 2018$ & 10 & 33 & 6 & 3 & 2 \\
\hline
\end{tabular}


Dimas Raya, Agustinus Yunan, Rifda Ilahy Rosihan

Submitted: 12/03/2020; Revised: 09/04/2020; Accepted: 05/06/2020; Published: 29/06/2020

\begin{tabular}{r|cccccc}
\multicolumn{1}{r}{17} & $1-9 / 7 / 2018$ & 10 & 32 & 5 & 3 & 2 \\
\cline { 2 - 7 } 18 & $10-18 / 7 / 2018$ & 9 & 32 & 5 & 2 & 1 \\
\hline & Total & 29 & 97 & 16 & 8 & 5 \\
\hline
\end{tabular}

Sumber: Data Perusahaan (2018)

Gambar Diagram Produk Crank Case dapat dilihat pada Gambar 2

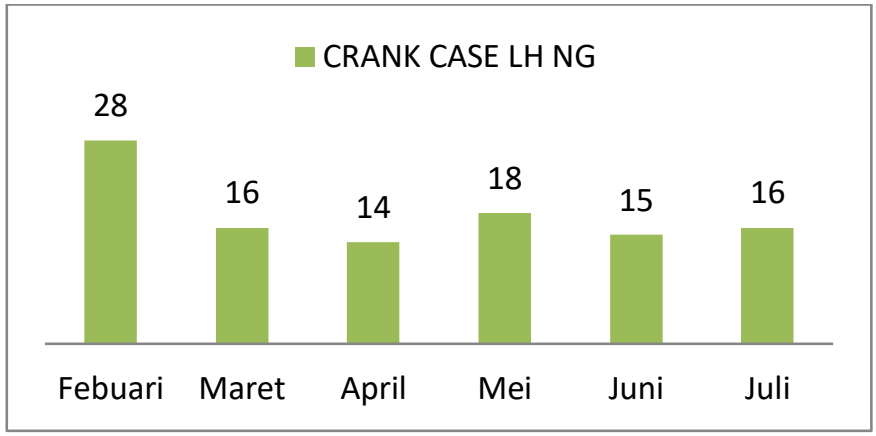

Sumber: Pengolahan Data (2019)

Gambar 2 Diagram Produk Crank Case LH yang Cacat

Tabel 4 Data Persentase Jumlah Defect pada Crank Case LH periode Febuari - Juli 2018

\begin{tabular}{|c|c|c|c|c|c|}
\hline jenis cacat & $\begin{array}{c}\text { Target Produksi } \\
\text { (6bulan) }\end{array}$ & $\begin{array}{c}\text { kegagalan } \\
\text { (defect) }\end{array}$ & $\begin{array}{c}\text { Total } \\
\text { (defect) }\end{array}$ & $\%$ & kumulatif \\
\hline $\begin{array}{c}\text { Crank Case LH } \\
\text { gompal }\end{array}$ & 1079 & 107 & 228 & $47 \%$ & 47 \\
\hline $\begin{array}{c}\text { Crank Case LH } \\
\text { retak }\end{array}$ & 1079 & 71 & 228 & $31 \%$ & 78 \\
\hline $\begin{array}{c}\text { Crank Case LH } \\
\text { kriput }\end{array}$ & 1079 & 50 & 228 & $22 \%$ & 100 \\
\hline
\end{tabular}

Gambar untuk Pareto chart pada Produk crank case dapat dilihat pada Gambar 3

\subsection{Diagram Sebab Akibat}

Setelah membuat pareto chart maka Langkah selanjutnya adalah membuat diagram sebab akibat atau yang biasa dikenal fishbone diagram untuk Produk crank case. Gambar untuk diagram Fishbone dapat dilihat pada Gambar 4, 5, dan 6.

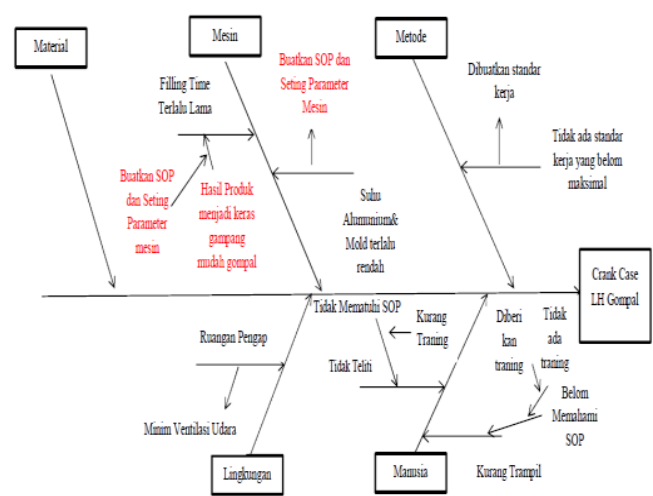

Sumber: Pengolahan Data (2019)

Gambar 4.Diagram Fishbone Produk Crank Case

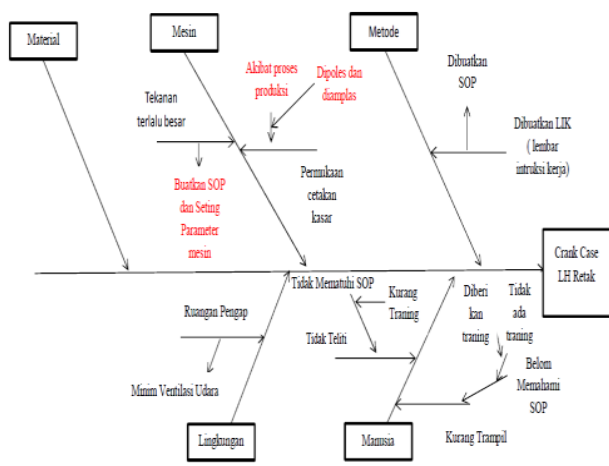

Sumber: Pengolahan Data (2019)

Gambar 5.Diagram Fishbone Produk Crank Case

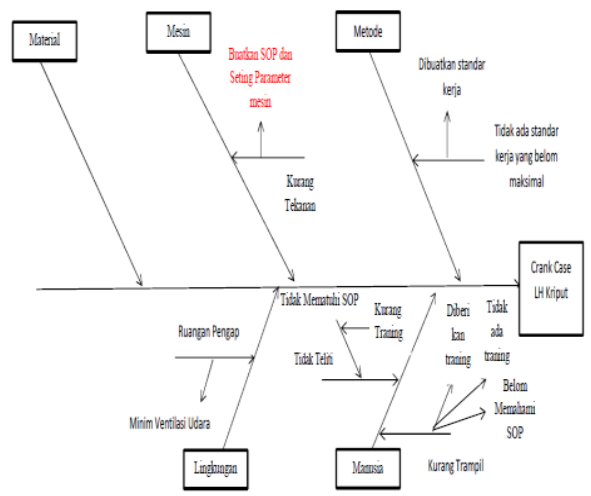

Sumber: Pengolahan Data (2019)

Gambar 6.Diagram Fishbone Produk Crank Case

6

Analisis Upaya Menurunkan Cacat Produk Crank Case LH pada Proses Die Casting dengan Metode PDCA dan 


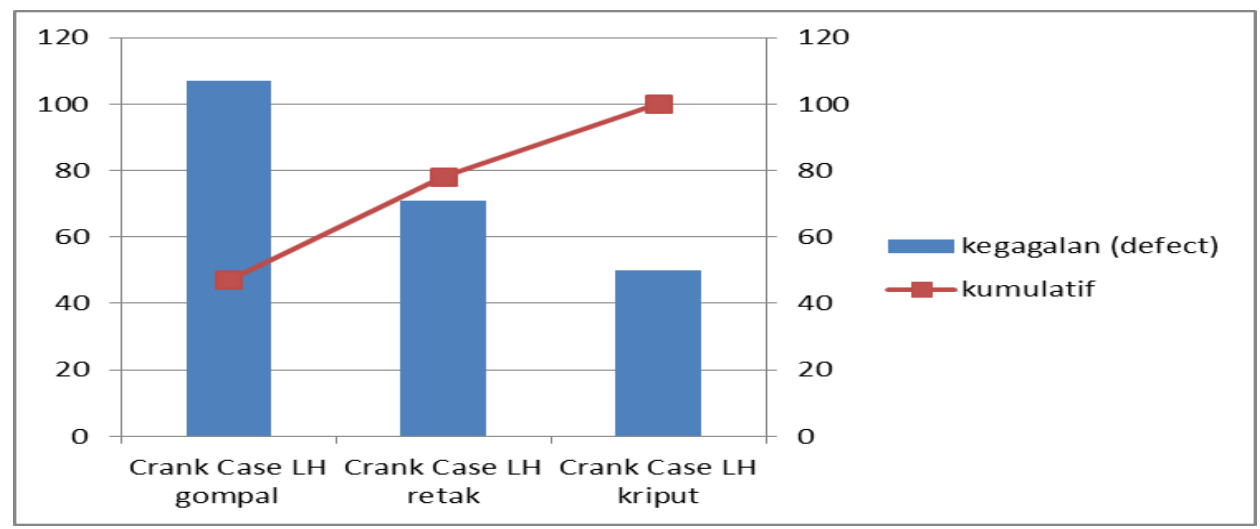

Sumber: Pengolahan Data (2019)

Gambar 3.Pareto Chart Produk Crank Case LH yang cacat

Tabel 5, 6 dan 7 merupakan tabel RPN untuk produk crank case

Tabel 5. Prioritas Pemecahan Masalah (Risk Priority Number)

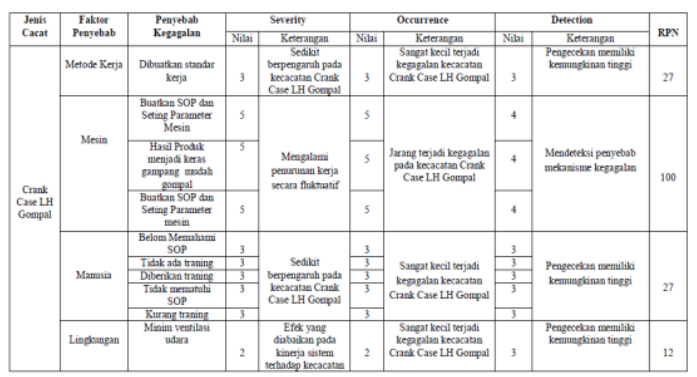

Sumber: Pengolahan Data (2019)

Tabel 6 Prioritas Pemecahan Masalah (Risk Priority Number)

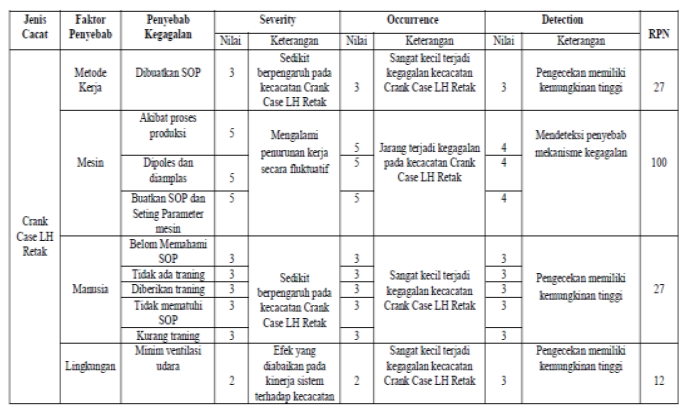

Sumber: Pengolahan Data (2019)
Tabel 7 Prioritas Pemecahan Masalah (Risk Priority Number)

\begin{tabular}{|c|c|c|c|c|c|c|c|c|c|}
\hline \multirow{2}{*}{$\begin{array}{l}\text { Jenis } \\
\text { Crat }\end{array}$} & \multirow{2}{*}{\begin{tabular}{c|}
$\begin{array}{c}\text { Falktor } \\
\text { Pencebab }\end{array}$ \\
\end{tabular}} & \multirow{2}{*}{ 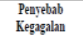 } & \multicolumn{2}{|r|}{ Serenity } & \multicolumn{2}{|r|}{ Occurrence } & \multicolumn{2}{|r|}{ Detertion } & \multirow{2}{*}{ RPX } \\
\hline & & & Nhai & $\begin{array}{l}\text { Keterangan } \\
\end{array}$ & Nhai & Keerangan & Naie & Ketrangan & \\
\hline \multirow{7}{*}{$\begin{array}{l}\text { Cank } \\
\text { Case LH } \\
\text { Keriput }\end{array}$} & $\begin{array}{l}\text { Metode } \\
\text { Kejaja }\end{array}$ & $\begin{array}{c}\text { Dibuatian standiar } \\
\text { kerja }\end{array}$ & 3 & 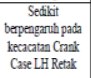 & 3 & 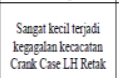 & 3 & 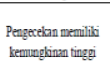 & 27 \\
\hline & Mein & 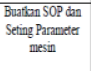 & 5 & 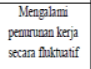 & 5 & 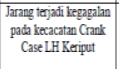 & 4 & $\begin{array}{l}\text { Mendetchis payyetab } \\
\text { medarisme kegagalan }\end{array}$ & 100 \\
\hline & \multirow{4}{*}{ Mansia } & $\begin{array}{l}\text { Belon Mematami } \\
\text { SOP }\end{array}$ & 3 & \multirow{4}{*}{ 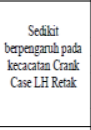 } & 3 & \multirow{4}{*}{ 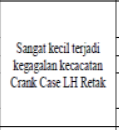 } & 3 & \multirow{4}{*}{$\begin{array}{l}\text { Pengectian nemilikj } \\
\text { kereanghinan tinggi }\end{array}$} & \multirow{4}{*}{27} \\
\hline & & Trudak ada traning & 3 & & 3 & & 3 & & \\
\hline & & 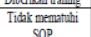 & 3 & & 3 & & 3 & & \\
\hline & & Kuranget traning & 3 & & 3 & & 3 & & \\
\hline & Linglungen & $\begin{array}{c}\text { Minim vectilusi } \\
\text { vdera }\end{array}$ & 2 & 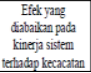 & 2 & 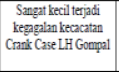 & 3 & $\begin{array}{l}\text { Peragectanan nemilikj } \\
\text { kemunghinan tinge }\end{array}$ & 12 \\
\hline
\end{tabular}

Sumber: Pengolahan Data (2019)

3.4 Menentukan dan Memperbaiki

Penyebab dari Akar Permasalahan

(Do)

Tabel 8 Tahapan Perbaikan Dari Segi Mesin

\begin{tabular}{cccc}
$\begin{array}{c}\text { Jenis } \\
\text { Problem/Cacat }\end{array}$ & September & Oktober & Total \\
\hline $\begin{array}{c}\text { Crank Case } \\
\text { LH Gompal }\end{array}$ & 8 & 7 & 15 \\
\hline $\begin{array}{c}\text { Crank Case } \\
\text { LH Retak }\end{array}$ & 7 & 6 & 13 \\
\hline
\end{tabular}


Dimas Raya, Agustinus Yunan, Rifda Ilahy Rosihan

Submitted: 12/03/2020; Revised: 09/04/2020; Accepted: 05/06/2020; Published: 29/06/2020

Crank Case

LH Keriput

Sumber: Pengolahan Data (2019)

Tabel 8 Tahapan Perbaikan Dari Segi Mesin

\begin{tabular}{|c|c|c|}
\hline Jenis & $5 \mathrm{~W}+1 \mathrm{H}$ & Deskripsi Tindakan (Mesin) \\
\hline Tujuan Utama & What (Apa) & $\begin{array}{l}\text { Suhu Alumunium\& Mold terlalu } \\
\text { rendah, Filling Time Terlalu Lama }\end{array}$ \\
\hline Alasan & Why (Mengapa) & $\begin{array}{l}\text { Buatkan SOP dan Seting Parameter } \\
\text { Mesin, Hasil Produk menjadi keras } \\
\text { gampang mudah gompal }\end{array}$ \\
\hline Orang & Who (Siapa) & Operator \\
\hline Tempat & Where (Dimana) & Departement Crank Case LH \\
\hline Waktu & When (Kapan) & Febuari-Juli 2018 \\
\hline Metode & How (Bagaimana) & $\begin{array}{c}\text { Dibuaatkan SOP dan seting } \\
\text { parameter sebelum kerja dimulai } \\
\text { agar produk yang kita buat sesuai } \\
\text { standar }\end{array}$ \\
\hline
\end{tabular}

Sumber: Pengolahan Data (2019)

Tabel 9 Tahapan Perbaikan Dari Segi Mesin

\begin{tabular}{|c|c|c|}
\hline Jenis & $5 \mathrm{~W}+1 \mathrm{H}$ & Deskripsi Tindakan (Mesin) \\
\hline Tujuan Utama & What (Apa) & $\begin{array}{l}\text { Permukaan cetakan kasar. } \\
\text { Tekanan terlalu besar }\end{array}$ \\
\hline Alasan & Why (Mengapa) & $\begin{array}{l}\text { Akibat proses produksi harus } \\
\text { Dipoles dann dianupins Bubatitan } \\
\text { SOOP dan Seting Parameter } \\
\text { mesin }\end{array}$ \\
\hline Orang & Who (Siapa) & Operator Die Casting \\
\hline Tempat & Where (Dimana) & Dapartemen Die Casting \\
\hline Waktu & When (Kapan) & Febuari-Juli 2018 \\
\hline Metode & How (Bagaimana) & $\begin{array}{l}\text { Sesudah proses proses } \\
\text { produksi cetakan mesin wajib } \\
\text { dibersikan supaya pas } \\
\text { produksi kembali tidak ada } \\
\text { kotor di dalem cetakan dan } \\
\text { operator sebelum kexja } \\
\text { mengecek dan seting } \\
\text { parameter mesin sesuai } \\
\text { standar }\end{array}$ \\
\hline
\end{tabular}

Sumber: Pengolahan Data (2019)

Tabel 10 Data Produk Cacat Setelah Perbaikan

\begin{tabular}{|c|c|c|}
\hline Jenis & $5 \mathrm{~W}+1 \mathrm{H}$ & Deskripsi Tindakan (Mesin) \\
\hline Tujuan Utama & What (Apa) & Kurang Tekanan \\
\hline Alasan & Why (Mengapa) & $\begin{array}{l}\text { Buatkan SOP dan Seting } \\
\text { Parameter mesin }\end{array}$ \\
\hline Orang & Who (Siapa) & Operator Dle Casting \\
\hline Tempat & Where (Dimana) & Dapartemen Die Casting \\
\hline Waktu & When (Kapan) & Juli-Desember 2018 \\
\hline Metode & How (Bagaimana) & $\begin{array}{l}\text { Supaya operator melihat SOP } \\
\text { yang telah ada dan seting } \\
\text { parameter mesin sebelum dan } \\
\text { sesudah kerja }\end{array}$ \\
\hline
\end{tabular}

Sumber: Pengolahan Data (2019)
$5 \quad 11$

3.5 Memeriksa atau Mengevaluasi Aktivitas Perbaikan (Check)

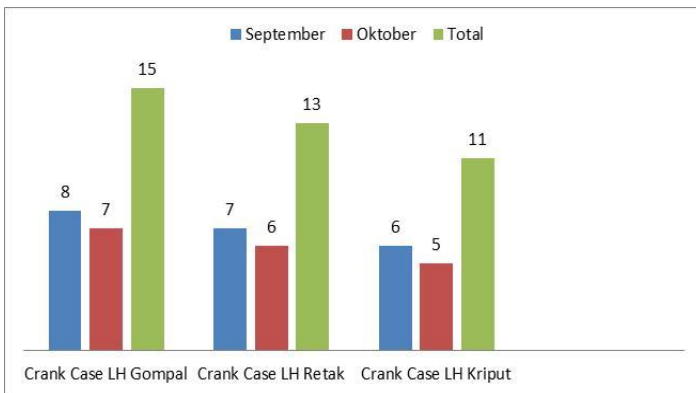

Sumber: Pengolahan Data (2019)

Gambar 7 Data Diagram Produk Cacat

Tabel 11 Data Produk Cacat Crank Case LH

\begin{tabular}{cccc}
\hline $\begin{array}{c}\text { Jenis } \\
\text { Problem/Cacat }\end{array}$ & $\begin{array}{c}\text { Rata-rata } \\
\text { sebelum/Unit } \\
\text { per bulan }\end{array}$ & $\begin{array}{c}\text { Jenis } \\
\text { Problem/Cacat }\end{array}$ & $\begin{array}{c}\text { Rata-rata } \\
\text { sesudah/Unit } \\
\text { per bulan }\end{array}$ \\
\hline $\begin{array}{c}\text { Crank Case LH } \\
\text { Gompal }\end{array}$ & 5 & $\begin{array}{c}\text { Crank Case LH } \\
\text { Gompal }\end{array}$ & 2 \\
\hline $\begin{array}{c}\text { Crank Case LH } \\
\text { Retak }\end{array}$ & 3 & $\begin{array}{c}\text { Crank Case LH } \\
\text { Retak }\end{array}$ & 2 \\
\hline $\begin{array}{c}\text { Crank Case LH } \\
\text { Kriput }\end{array}$ & 2 & $\begin{array}{c}\text { Crank Case LH } \\
\text { Kriput }\end{array}$ & 1 \\
\hline
\end{tabular}

Sumber: Pengolahan Data (2019)

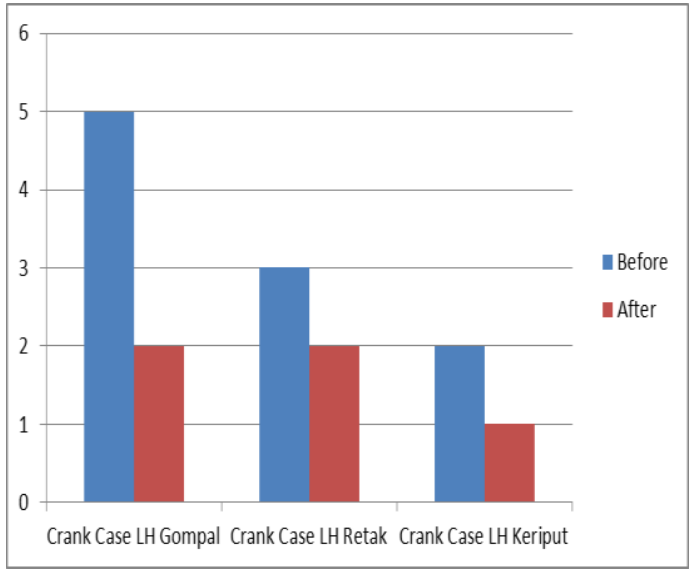

Sumber: Pengolahan Data (2019)

Gambar 8 Data diagram Perbandingan

8

Analisis Upaya Menurunkan Cacat Produk Crank Case LH pada Proses Die Casting dengan Metode PDCA dan 


\subsection{Standarisasi Hasil (Action)}

Tabel 12 Usulan Standarisasi Hasil

\begin{tabular}{ccll}
\hline No & Faktor & Standarisasi & \multicolumn{2}{c}{ Point Penting } \\
\hline 1 & Mesin & Membuat SOP & Adanya SOP \\
& & mesin dan & mesin dan \\
& & seting & seting parameter \\
& & parameter & mesin \\
& & mesin dalam & berkurangnya \\
& & kondisi yang & tingkatnya \\
& & terbaik supaya & kerusakan pada \\
& hasil produksi & produksi yang \\
& sesuai & kita hasilkan . \\
& & perencanaan & \\
\hline
\end{tabular}

Sumber: Pengolahan Data (2019)

\section{KESIMPULAN}

\section{Kesimpulan}

Berdasarkan hasil pengolahan data dan analisia, yang telah dilakukan penelitian dengan menggunakan metode PDCA dengan FMEA di PT. Suzuki Indo Mobil/Motor, maka penulisan dapat membuat sebuah kesimpulan antara lain yaitu:

1. Berdasarkan hasil analisa penelitian dengan menggunakan diagram sebab akibat dan tingkatan Risk Priorty Number tertinggi dapat diketahui akar penyebab masalah yaitu 1 faktor penyebab yang memungkinkan dapat menyebabkan cacat yaitu : mesin, adapun penyebabnya adalah: Faktor Mesin

a. Faktor ini disebabkan karena Suhu Alumunium \& Mold terlalu rendah, maka dibuatkan SOP dan seting ulang parameter mesin

b. Faktor ini disebabkan karena filling time terlalu lama, maka dibuatkan SOP dan seting parameter mesin biar hasil produksi sesuai target yang kita inginkan c. Faktor ini disebabkan karena permukaan cetakan kasar hasil produksi menjadi NG, kami sarankan permukaan cetakan kasar harus dipoles dan diamplas

d. Faktor ini disebabkan karena tekanan mesin terlalu besar mengakibatkan hasil produksi menjadi NG, maka dibuatkan SOP dan seting parameter mesin sesuai standar

e. Faktor ini disebabkan karena kurang tekanan mengakibatkan hasil produksi kurang maksimal, maka dibuatkan SOP dan seting parameter mesin sesuai standar

2. Usulan perbaikan pengendalian kualitas terdapat di How dalam tahapan $5 \mathrm{~W}+1 \mathrm{H}$ serta di dalam fase Do (Menentukan dan memperbaikan dari akar permasalahan)

\section{Saran}

Saran dari penelitian ini adalah Menjalankan dan menindak lanjutkan hasil dari stadarisasi yang dibuat oleh penulis kemudian menerapkan perbaikan secara berkesinambungan atau berkala dengan melakukan penerapan metode PDCA dan FMEA disetiap problem kualitas maupun tidak dan untuk penelitian selanjutnya dapat menggunakan analisis pengendalian kualitas dengan metode Six Sigma sebagai pembanding pengendalian kualitas

\section{DAFTAR PUSTAKA}

Ariani, D.W., 2004, Pengendalian Kualitas Statistik (Pendekatan Kuantitatif dalam Manajemen Kualitas). Andi: Yogyakarta.

Assauri, Sofjan, 2004, Manajemen Produksi dan Operasi Edisi Revisi 2004. Jakarta: Lembaga Penerbit FE-UI 
Ferdian, Anthony C., 2016, Implementasi Pengendalian Kualitas Dengan Menggunakan Pendekatan Seven Tools dan FMEA Pada CV. Madu Gong di Mojokerto, Skripsi, Fakultas Bisnis dan Ekonomika, Universitas Surabaya.

Singh, A.P. 2013. Quality Improvement Using Statistical Process Control Tool in Glass Bottles Manufacturing Company. International Journal for Quality Research, Vol. 7, 107-126.

Subali, S. B. W., dan Setyawan, A. B. 2016. The Implementation of Seven Quality Management Tools: Experiences From Three Enterprises in East Java, Indonesia. 13th Ubaya International Annual Symposium On Management.

Varsha M. M., Dr. Vilas B. S.2014. Application of 7 Quality Control (7 QC) Tools for Continuous Improvement of Manufacturing Processes. International Journal of Engineering Research and General Science. Vol 2 (4): 2091-2730 